\title{
SOCIÁLNA OPORA U ŽIAKOV RÓMSKEHO ETNIKA
}

\author{
MARIANNA ŠRAMKOVÁ
}

\begin{abstract}
Abstrakt: Práca je zameraná na problematiku sociálnej opory u žiakov rómskeho etnika, ktorí sa nachádzajú vo vývinovom období pubescencie. Ciel'om výskumu bolo zmapovat' sociálnu oporu - konkrétne jej zdroje (mama, otec, učitel', kamaráti, spolužiaci, asistent učitel'a, sociálny pracovník) a druhy (emocionálna, inštrumentálna, hodnotiaca a informačná) v častosti a dôležitosti vnímanej sociálnej opory. Čiastkový ciel' sa týkal porovnania zdrojov a druhov sociálnej opory vzhl’adom na typ osídlenia, v ktorom žijú respondenti. Výskumnú vzorku tvorilo 79 žiakov siedmeho až deviateho ročníka základnej školy v Rakúsoch. Rakúsy sa zarad’ujú medzi obce s jedným z najvyšších podielov rómskej populácie na Slovensku. Na výskume participovalo 46 chlapcov a 33 dievčat, 61 žiakov pochádzalo z osady a 18 žiakov z dediny. Uskutočnili sme zámerný kvalifikovaný výber. Nosnou metódou bol dotazník CASSS-CZ (Dotazník sociální opory u dětí a dospívajících - česká verze), d’alšie údaje sme doplnili ešte štruktúrovaným interview. Použili sme popisnú štatistiku a párový U-test. Z výsledkov výskumu vyplýva, že žiaci najčastejšie získavajú sociálnu oporu od matky, ktorá je pre nich aj najdôležitejším zdrojom. Najmenej dôležitým zdrojom opory je pre nich učitel'. Najmenej je im poskytovaná opora od sociálneho pracovníka. Čo sa týka jednotlivých druhov opory najviac je im poskytovaná informačná opora, ale dôležitá je pre nich opora emocionálna. Potvrdili sa niektoré štatisticky významné rozdiely v jednotlivých druhoch a zdrojoch sociálnej opory vzhl'adom na typ osídlenia respondentov. Prínosom práce sú zistené preferované zdroje a druhy opory u detí rómskeho etnika a následné odporúčania do praxe.
\end{abstract}

Kl'účové slová: sociálna opora; zdroje sociálnej opory; druhy sociálnej opory; pubescenti

\section{Social support of pupils of the Roma ethnic group}

Abstract: The paper is focused on the issue of social support of pupils of the Roma ethnic group who are in the adolescence. The aim of the research was to map social support - namely its resources (mom, father, teacher, friends, classmates, teacher assistant, social worker) and types (emotional, instrumental, provided through evaluation and information) in the frequency and importance of perceived social support. The secondary goal was to compare the resources and types of social support with respect to the type of settlement in which respondents live. The research sample consisted of 79 pupils of the seventh to ninth year of elementary school in Rakúsy. Rakúsy rank among the municipalities with one of the highest shares of the Roma population in Slovakia. 46 boys and 33 girls participated in the research, 61 pupils came from the outpost and 18 pupils from the village. We made a deliberate qualified selection. The main method was the CASSS-CZ questionnaire (Questionnaire of social support of pupils and adolescents - Czech version), further data was supplemented by a structured interview. We used descriptive statistics and pair U-test. Research shows that pupils most often receive social support from their mother, who is also the most important source for them. The least important source of 
support for them is the teacher. Smallest support is provided from a social worker. As far as the individual types of support are concerned, they are mostly provided with informational support, but emotional support is important as well. Some statistically significant differences in individual types and sources of social support were confirmed with respect to the type of settlement of respondents. Contribution of the article is to find out the preferred sources and types of support in children of the Roma ethnic group and subsequent recommendations to practice.

Keywords: social support; sources of social support; types of social support; teenagers https://doi.org/10.14712/23366486.2019.7

\section{Úvod}

L’udia i sociálnopsychologické javy sú zasadené do fyzikálneho a sociálneho (sociálna siet') kontextu a nemôžeme ich z neho vytrhovat' (Výrost, Slaměník, 2001). Každý človek ku svojmu úspešnému vývinu potrebuje druhých l'udí. Je mu príznačná tendencia združovat' sa, žit' v sociálnom prostredí, ktoré je tvorené práve l'ud'mi a ich vzájomnými vzt’ahmi, ich spoločnými aktivitami, či produktmi týchto aktivít a vzt'ahov. ,,Sociálne prostredie je nevyhnutnou súčastou životného prostredia človeka, so špecifickými znakmi a charakteristikami, ktoré život v spoločnosti prináša “ (Kollárik, 2002, s. 10). Sociálna integrácia človeka, medzil'udské väzby, akákol'vek interpersonálna interakcia determinuje človeka a vo významnej miere ovplyvňuje jeho správanie a prežívanie.

\section{Teoretické východiská}

Problematika sociálnej opory je vel'mi široká. Venovali a venujú sa jej niektorí slovenskí (Gecková, Pudelský, Tunistra, 2000; Medved’ová 2001, 2004; Schraggeová1993; ...) ale najmä zahraniční autori (Mareš, 2001, 2002, 2004; Křivohlavý, 1999, 2001, 2009; Kebza, 2005; Koubeková, 1997, 2002; Kožený, Tišanská, 2003; Sarason, Sarason, Pierce, 1994; Bokhorst, Sumter, Westenberg, 2010; Šolcová, 2009; ...). Predmetom ich výskumov bola najmä sociálna opora u dospelej populácie. Vo vedeckých, či odborných knihách, článkoch však chýbajú výskumy týkajúce sa sociálnej opory detí a dospievajúcich pochádzajúcich zo špecifického sociálneho prostredia, a to sociálne znevýhodňujúceho, $\mathrm{v}$ našom prípade konkrétne $\mathrm{z}$ rómskej osady. Rómska populácia sa pravidelne objavuje medzi skupinami označovanými ako najviac ohrozenými chudobou a sociálnym vylúčením. „Pre čast' obyvatel'ov chudobných a vylúčených rómskych osídlení je typická absolútna chudoba, ktorá je prenášaná medzigeneračne a je spojená so sociálnym vylúčením, vrátane priestorovej segregácie " (Rusnáková, Rochovská, 2014, s. 162). Naliehavost' riešenia problémov rómskych komunít na Slovensku je daná nielen ich neustále sa zhoršujúcimi podmienkami pre život, ale aj stupňujúcim sa napätím vo vzt’ahu k majoritnému obyvatel'stvu.

Vychádzajúc z dvojdimenzionálnej klasifikácie copingových stratégií, ktorú vytvorili Folkman, Lazarus (1984) a na ktorú naviazal aj Tobin, Hobroyd, Reymolds (1984) a vytvoril hierarchický model copingových stratégií, považujeme sociálnu opora za jednu z copingových stratégií. Mareš et al. vnímajú sociálnu oporu ako ,,uspokojenie základných sociálnych potrieb prostredníctvom sociálnej interakcie“"(Mareš, Rybárová, Lašek, 1996, 
s. 102). Křivohlavý ju v širšom zmysle slova definuje ako ,pomoc, ktorá je poskytovaná druhými l'ud'mi človeku, ktorý sa nachádza v zát'ažovej situácii. V̌̌eobecne ide o činnost', ktorá človeku v tiesni jeho zát’ažovú situáciu určitým spôsobom ul’ahčuje " (Křivohlavý, 2001, s. 94). Trochu odlišné chápanie sociálnej opory nájdeme u Koubekovej, ktorá ju charakterizuje ako ,, súbor vztahov, ktoré jedinec percipuje v komunikačnej sieti ako subjektívne významné pre zachovanie vlastnej identity a psychickej rovnováhy “ (Koubeková, 1997, s. 107). Taktiež ju považuje za zdroj kvality života. O sociálnej opore možno hovorit' aj ako o uspokojovaní základných potrieb človeka prostredníctvom interakcie s iným človekom, prípadne interakcie s inými l’ud'mi. K základným sociálnym potrebám človeka patrí napríklad potreba byt' milovaný, vážený a uznávaný, tiež potreba niekam patrit', potreba identity a potreba bezpečia (Čáp, Mareš, 2007). Nejednotnost'v definíciách a rozdiely v chápaní fenoménu sociálnej opory sa môže zdat' chaotická, vyplýva však z toho, že sociálna opora je mnohostranný koncept.

Zdrojmi sociálnej podpory je sociálna siet', do ktorej môžeme podl'a Kebzu (2005) zaradit' rodinu, blízkych priatel'ov, susedov, spolupracovníkov, komunitu a profesionálov. „Sociálna siet' je teda súbor l'udí okolo danej osoby, s ktorými je, alebo bola táto osoba v sociálnom kontakte a od ktorých je možné očakávat', že by jej v prípade potreby poskytli určitú pomoc “ (Křivohlavý, 2001, s. 94-95). Extrémnym pólom dimenzie sociálnej opory je sociálna izolácia, čiže absencia sociálnej opory, opustenost’ človeka. Pri zdrojoch je vel'mi dôležité sa zaoberat' otázkou kvantity a kvality. Množstvo podporných vzt'ahov nehovorí o ich kvalite. Ak má jednotlivec vo svojom okolí vel'ké množstvo takýchto vzt'ahov, nemusí to znamenat', že jeho okolie mu poskytuje maximálnu sociálnu oporu (Šolcová, Kebza, 1999).

Ked' hovoríme o sociálnej opore, je dôležité si uvedomit' a rozlíšit', aký druh pomoci máme na mysli a aké funkcie napĺn̆a. Křivohlavý (2001) rozlišuje tieto druhy:

- Inštrumentálnu oporu - ide tu o konkrétnu formu pomoci, napr. poskytnutie financií, materiálnych vecí.

- Informačnú oporu - tu ide o poskytnutie informácie, ktorá by mohla pomôct' danému človeku orientovat' sa v situácii.

- Emocionálnu oporu - prostredníctvom ktorej naznačujeme človeku náklonnost', rešpekt, úctu, dodávame nádej.

- Hodnotiacu oporu - tú dávame osobe v tiesni tým, ked’ posilňujeme jej kladné sebahodnotenie a sebavedomie, ked' podporujeme jeho snahu o autoreguláciu.

Podl'a iných kritérií môžeme rozlíšit' individuálnu sociálnu oporu a inštitucionálnu sociálnu oporu, podl'a toho, či je zdrojom človek alebo inštitúcia.

Súhlasíme však s názorom Doňkovej, ktorá tvrdí, ,že rôzne druhy sociálnej opory spolu navyše úzko súvisia, teda zistovanie ich samotného vplyvu bez podielu ostatných je vel'mi nel'ahké. Nutné je taktiež podotknút', že pôsobenie špecifických druhov sociálnej opory je naprieč rôznymi životnými udalost’ami odlišné “ (Doňková, 2013, s. 48). Jednotlivé druhy sociálnej opory tak môžu byt' človekom považované za vel'mi prospešné od jedných poskytovatel'ov, pričom od iných sa môžu míňat' účinkom - alebo pôsobit' skôr negatívne.

Sociálna opora má všeobecný vplyv takmer vo všetkých oblastiach života a zapojenie určitých zdrojov je vel'mi ovplyvňované vekom. Zdroje sa pochopitel'ne odlišujú v rannom detstve, v období dospievania, v dospelosti a v starobe. Ked’že naši respondenti sa nachádzali vo vývinovom období pubescencie a žili v špecifickom sociálnom prostredí, 


\section{vychádzali sme aj z charakteristiky - z konceptu obdobia pubescencie, dôraz sme kládli na špecifiká rómskeho pubescenta a sociálne znevýhodneného prostredia.}

Puberta alebo starší školský vek sa vymedzuje ako obdobie, ktoré trvá od 10-11 rokov do 15-16 rokov. Podl'a Eriksona je obdobie puberty charakteristické hl'adaním a vytváraním vlastnej identity, bojom s neistotou a pochybnost'ami o samom sebe, o svojej pozícii v spoločnosti (Vágnerová, 1999). Oravcová, Kariková (2011, s. 43) obdobie pubescencie charakterizujú ako „, snád’ najdynamickejšie obdobie vývinu, ktoré je sprevádzané komplexnou premenou jednotlivca, ktorá sa určitým spôsobom dotýka všetkých stránok jeho osobnosti. Pubescenti preživajú vývinové obdobie, v ktorom u nich nastáva premena v oblasti pohlavného dospievania, prežívania, v oblasti procesu socializácie a s tým aj spojenej vol'by profesie, zmenou sociálnych roli a napokon zmenou vlastnej identity. Mnohé ich osobnostné charakteristiky sú relatívne, vychádzajú $z$ porovnania s ostatnými - a to ako $v$ zmysle identifikácie - stotožnenia, tak v zmysle diferenciácie - odlíšenia. “

Rómsky pubescent sa v niektorých smeroch odlišuje od pubescentov majoritnej spoločnosti. Tieto rozdiely sú dôsledkom zachovávania vlastných pravidiel rómskeho etnika a jeho odlišným štýlom života. Niektoré rozdiely v správaní a prežívaní vyplývajú podl'a Vágnerovej (2000) aj z odlišnosti vrodených dispozícií, napr. temperamentových, ktoré sa však nedajú menit'. Odlišná genetická výbava je predpokladom k preferencii špecifických spôsobov správania, zvládania zát’ažových situácií a celkového životného štýlu.

Rómskym pubescentom v prvom rade chýba potreba väčšieho zdôraznenia indivídua, ked’že výchova $\mathrm{v}$ rómskych rodinách $\mathrm{k}$ individualite nesmeruje a ani ju nepocit’ujú ako hodnotu. Z toho dôvodu sa u nich nerozvíja sút’aživost', motivácia k vyniknutiu v skupine a vyššia osobná ašpirácia. S individualitou súvisí aj sebahodnotenie, ktoré je u nich vel'mi nízke a sebaponímanie. Rómovia nemajú tendenciu ku introspekcii a k sebapoznávaniu. Akceptujú svoju osobnost' takú, aká je i v období dospievania, kedy sa bežne objavuje potreba zmeny a aktívneho rozvoja vlastnej identity. U rómskych pubescentov to tak nie je, väčšinou nemajú žiadny ideál, ktorý by im slúžil ako vzor. ,,Ich prístup k sebe samému je prezentisticky realistický, vlastná osobnost' je akceptovaná ako danost'. Ked’že chýba tendencia o sebe uvažovat', chýba i motivácia ku akejkolvek osobnostnej zmene" (Vágnerová, 2000, s. 257). Nepremýšl'ajú o sebe a ani sa aktívne neusilujú o zmenu zameranú do budúcnosti. Dá sa to zdôvodnit' tým, že ich čas sa obmedzuje iba na rozmer aktuálne prežívanej prítomnosti, kým minulost' a hlavne budúcnost' sú na okraji ich vnútorného času, príliš sa o budúcnost' nestarajú, ale veria, že bude lepšia.

Nevýhodou orientácie na prítomnost' však často býva nedostatok disciplíny, spol'ahlivosti a vytrvalosti. „,Rómske diet’a máva problémy, ked’ sa má prinútit' $k$ nezáživnému učeniu, športovo nadani chlapci odpadajú pre neschopnost' pravidelne trénovat', hudobné talenty často vyhasnú pre neochotu naučit’ sa notám “ (Ř́čcan, 1998, s. 54). Deti majú vol'ný vzt'ah k času a k povinnostiam, ktoré sú s ním spojené.

Výrazné odlišnosti sú najmä v odlišnom postavení rómskych dievčat, týkajúcich sa prevzatia rodovo určených rôl. Rómske dievčatá sú počas školskej dochádzky neustále konfrontované s postavením dievčat'a a ženy vo vlastnej a majoritnej kultúre. Dievča vo veku 10-12 rokov často preberá v rodine funkciu matky a stará sa o mladších súrodencov a o pár rokov neskôr sa už aj ono stáva matkou. Možná nespokojnost' so ženskou rolou, ktorú sú nútené prevziat' už počas neskorej puberty, pravdepodobne ovplyvňuje aj ich prežívanie a sebahodnotenie. Podl'a Kotekovej (1998) a Kundrátovej (2003) čo sa týka 
prežívania rómskych dievčat, kým v mladšom veku sa túžia priatelit’ s nerómskymi dievčatami, obdivujú ich, dokonca sa snažia s nimi identifikovat', v puberte sa toto pozitívum mení až na nepriatel'ský postoj a to tým, že napriek snahe sú do majoritnej skupiny neprijímané. Koteková (1998) tvrdí, že s týmto javom (s neakceptovaním zo strany nerómskych detí) sa podstatne lepšie vyrovnávajú rómski chlapci.

Výraznou hodnotou je pre nich uznávanie rodovej hierarchie a rodovej tradície. Vzhladom k dodržiavaniu zložitých rodových zvykov a pravidiel nedochádza v období dospievania k extrémnemu vyhroteniu konfliktov generačného rázu.

Rómovia majú iné temperamentové vlastnosti. ,Ich emotivita je význačná vzrušivostou, impulzivitou a väčšou intenzitou a bohatstvom preživaných emócií. Nedostatočné ovládanie citových prejavov je zrejmé už v detskom veku a býva často hodnotené ako porucha správania“ (Vágnerová, 2000, s. 259). Častejšie sa u nich prejavujú výkyvy nálady, aj prejavy sú nápadnejšie a menej zvládnuté. Sú citovo spontánní, bezprostrední, otvorení, extrovertní, viac prejavujú agresivitu a typické je pre nich jednorazové afektívne správanie. Taktiež sa vyznačujú precitlivelost'ou, sklonom k predvádzaniu, demonštratívnost'ou a tendenciou vymáhat' si okamžité uspokojenie potrieb, bez ohl'adu na ich d'alšie dôsledky. V oblasti autoregulácie prevažujú emócie nad vôl'ou. Aj rómsky štýl uvažovania je typický väčším vplyvom aktuálnych emócií. Majú extrémne vyvinutý zmysel pre nonverbálnu komunikáciu a špecifické umenie empatie. Ich dorozumievanie prebieha pomocou výraznej mimiky, gestikulácie, haptiky, posturológie.

Myslenie rómskych detí je pragmatické a pomáha im prežit' v najrozličnejšom prostredí. Vágnerová (2000) poukazuje na dobrú schopnost' riešit' bežné praktické situácie s uspokojením aktuálnych potrieb. Abstraktné, či logické uvažovanie nemá pre nich vel'ký osobný význam. V poznávacom štýle rómskych školákov sa však neprejavuje sklon ku strereotypu a rigidite, čiže sa nedá zovšeobecnit', že by boli mentálne handicepovaní, ale štruktúra ich inteligencie je iná. Hlubocký (in Bakalář, 2004) hovorí o rómskom disperzne zníženom intelekte. Rozvíjajú sa tie zložky intelektu, ktoré sú im užitočné. Ukázalo sa, že títo l'udia majú iné problémy a bežné životné situácie vnímajú inak, než je zvykom v majoritnej spoločnosti. Majú iný prístup k úlohám a štandardne nízku výkonovú motiváciu. Často sa na školskom zlyhaní významne podiel'a nedostatočne rozvinutá vôl'a a sebaovládanie. Pevný rytmus školy predstavuje pre rómskeho žiaka vel'kú zát'až. Prejavuje sa to nielen neschopnost'ou pravidelnej prípravy do školy, ale aj neskorými príchodmi do nej či až záškoláctvom. Je to výsledok vol'nej, nedirektívnej výchovy, dostatkom vol’ného času a minima povinností.

Rusnáková (2007) však tvrdí, že vyššie spomenuté charakteristiky, na ktoré poukazujú mnohé výskumy, sa nemusia týkat' iba rómskych detí, ale platia najmä pre deti zo sociálne znevýhodneného prostredia. Mnoho vlastností, čŕt, ktoré vo všeobecnosti pripisujeme Rómom, nesúvisia s etnikom ako takým, ale so životnými stratégiami, ktoré súvisia s chudobou. Vel'a rómskych pubescentov, ktorí nežijú v segregovaných osadách a netrpia chudobou sa v mnohom nelíšia od pubescentov majoritnej spoločnosti.

Mnohí naši respondenti však pochádzajú, žijú v sociálne znevýhodnenom prostredí (znevýhodnené chudobou alebo kultúrou). Toto prostredie definujeme ako ,pprostredie, ktoré vzhl'adom na sociálne a jazykové podmienky nedostatočne stimuluje rozvoj mentálnych, vôl'ových a emocionálnych vlastností jednotlivca, nepodporuje jeho efektívnu socializáciu a neposkytuje dostatok primeraných podnetov pre rozvoj osobnosti. Spôsobuje sociálno-kultúrnu depriváciu, deformuje intelektuálny, mravný a citový rozvoj 
jednotlivca a z aspektov edukácie ho z týchto dôvodov považujeme za osobu so špeciálnymi výchovno-vzdelávacími potrebami.

\section{Výskumný ciel'}

Práca sa zaoberá problematikou sociálnej opory. Ako tvrdia Mareš a Ježek, ,ide o dynamický proces, ktorého forma a úroven̆ sa premieňa v čase, mení sa v závislosti na situáciách, životných udalostiach, na veku a sociálnej začlenenosti jedinca " (Mareš, Ježek, 2005, s. 6). My sme sa zamerali na skúmanie sociálnej opory u žiakov rómskeho etnika, ktorí sa nachádzajú vo vývinovom období pubescencie. V období, ktoré je okrem iného charakterizované i zmenami vzt’ahov, postupným prechodom od rodiny k rovesníkom a iným sociálnym skupinám. Čo sa týka sociálnej začlenenosti, rómska populácia patrí medzi skupiny, ktoré sú najviac ohrozené chudobou a sociálnym vylúčením. Mnohí naši respondenti pochádzali práve z marginalizovaných rómskych komunít. Základným ciel'om našej práce bolo zmapovat', zistit' ich vnímanú mieru a dôležitost' sociálnej opory (jej zdrojov a druhov). Čiastkový ciel' sa týkal porovnania zdrojov a druhov sociálnej opory vzhl'adom na bydlisko (typ osídlenia) našich respondentov.

\section{Výskumné otázky a hypotézy}

Výskumné otázky a hypotézy (v súlade s ciel'om práce) boli zamerané najmä na zdroje a druhy sociálnej opory.

\section{VÝSKUMNÉ OTÁZKY}

1. Ktorý druh poskytovanej sociálnej opory budú považovat' respondenti za najdôležitejší?

2. Ktorý druh sociálnej opory bude respondentom najčastejšie poskytovaný?

3. Ktorý zdroj sociálnej opory bude respondentmi najviac preferovaný? Budú to rodičia?

4. Budú sa líšit' zdroje sociálnej opory a jej druhy vzhl’adom na typ osídlenia respondentov?

\section{Hypotézy}

Hy1.: Predpokladáme, že existujú štatisticky významné rozdiely v jednotlivých zdrojoch sociálnej opory (mama, otec, učitel', kamaráti, spolužiaci, asistent učitel'a, sociálny pracovník) v častosti a dôležitosti vnímanej sociálnej opory u žiakov žijúcich v osade a u žiakov žijúcich v dedine.

Hy2.: Predpokladáme, že existujú štatisticky významné rozdiely v jednotlivých druhoch sociálnej opory (emocionálna, inštrumentálna, hodnotiaca a informačná) v častosti a dôležitosti vnímanej sociálnej opory u žiakov žijúcich v osade a u žiakov žijúcich $\mathrm{v}$ dedine.

Našu výskumnú vzorku tvorilo 77 \% respondentov žijúcich v segregovanej komunite - osade (tento pojem je využívaný aj samotnými Rómami a má svoj ekvivalent 
v rómskom jazyku - romano gav) vzdialenej kilometre od „materskej“ dediny a $23 \%$ žijúcich rozptýlene medzi majoritným obyvatel’stvom v dedine. Rusnáková a Rochovská zdôrazňujú, že ,„život v segregácii má dopady v mnohých oblastiach života domácnosti. Takmer neexistujúce materiálne zdroje domácností, vel'mi limitovaný prístup $k$ zamestnaniu a vzdelaniu, odkázanost’ na pomoc štátu, limitované sociálne siete. Práve posledné spomenuté - sociálne siete a väzby zohrávajú významnú úlohu pri možnej sociálnej inklúzii, alebo naopak, upevňujúcej sa sociálnej exklúzii “ (Rusnáková, Rochovská, 2014, s. 166). Ako tvrdí Radičová (2001) Rómovia žijúci segregovaní v marginalizovanom území vytvárajú uzatvorené spoločenstvo s homogenizovanou štruktúrou, kde existuje len jeden vzorec sociálneho správania sa a jednej životnej stratégie. Táto životná stratégia je fenoménom znásobenej kultúrnej závislosti, ktorá sa navonok prejavuje výraznou pasivitou, rezignáciou a apatiou. ,S priestorovou segregáciou úzko súvisí aj minimálna miera sociálnych kontaktov s vonkajšim prostredím. Čím je komunita alebo susedstvo homogénnejšie a endogénnejšie, tým je uzavretejšia voči vonkajšiemu prostrediu, ale na druhej strane jednotlivé rodiny sú otvorenejšie voči vplyvu svojej komunity. Komunita sa stáva kontrolným mechanizmom “ (Džambazovič, 2007, s. 437). Majoritná spoločnost' sa takýmto oblastiam začína vyhýbat', narastá vnútorná kohézia spoločenstva a komunita sa začína uzatvárat' (Rusnáková, Rochovská, 2014). Deti žijúce v izolovaných osadách majú - okrem navštevovania školského zariadenia - len vel'mi málo príležitostí na vstup do ,iného“ prostredia. A navyše ich škola je etnicky homogénna. Čiže majú minimálne kontakty s nerómskym obyvatel'stvom. ,, Schopnost' vytvárat' vzt'ahy s Nerómami, budovat' siete, sú považované za dôležitú zručnost', ktorá zjednodušuje prístup k rôznym zdrojom (práca) a napomáha sociálnej inklúzii. Naopak, chýbajúce sociálne siete s nerómskym obyvatel'stvom ešte viac zdôrazňujú znevýhodnenia vyplývajúce z priestorovej segregácie “ (Rusnáková, Rochovská, 2014, s. 168-170). V našom výskume sme chceli zistit', či sa žiaci žijúci v osade(izolovaní od sociálnych zdrojov s nerómskym obyvatel'stvom) budú snažit' získat' v školskom prostredí, kde sú v kontakte s l'ud'mi majoritnej spoločnosti, čo najviac opory, podpory, spolupatričnosti - alebo budú pri prijímaní a vyhl'adávaní opory viac zdržanliví, než žiaci žijúci v dedine medzi majoritou.

\section{Výskumný súbor a použité metódy}

Uskutočnili sme zámerný kvalifikovaný výber. Aby sme predchádzali etickým a diskriminačným otázkam (na základe čoho sme určili, že je daný žiak Róm) vychádzali sme z Atlasu rómskych komunít. Tento dokument postupoval pri určovaní (či je daný človek Róm) metódou kvalifikovaného odhadu. Čo znamená, že daný človek nie je oficiálne Róm, ale je mu pripisovaná rómska etnicita. Atlas rómskych komunít poskytuje informáciu, že najviac Rómov žije v okrese Kežmarok. Obec Rakúsy sa nachádza 7 kilometrov severne od Kežmarku. Z $\mathbf{2 8 8 5}$ obyvatel'ov je 540 Nerómov. Tým sa Rakúsy zarad’ujú medzi obce s jedným z najvyšších podielov rómskej populácie na Slovensku. 230 Rómov žije priamo v obci, v rómskej osade je to viac ako 1400 Rómov. Tým sa rómska osada v Rakúsoch stáva najväčšou v kežmarskom okrese a jednou z najväčších na Slovensku vôbec.

Výskumnú vzorku tvorilo 79 žiakov (navštevujúcich bežné triedy) siedmeho, ôsmeho a deviateho ročníka základnej školy v Rakúsoch, ktorých vek sa pohyboval v rozmedzí 12-15 rokov (s priemerným vekom 13,82 rokov). Na výskume participovalo 46 chlapcov 
a 33 dievčat, 61 žiakov pochádzalo z osady a 18 žiakov z dediny. Sme si vedomí, že do skúmaného vývinového obdobia patria aj žiaci piateho a šiesteho ročníka základnej školy, avšak do výskumného súboru sme ich nezaradili vzhl'adom na výber použitej metodiky.

K zisteniu percipovanej sociálnej opory (jej miery a dôležitosti pre prijímatel'a) u žiakov sme použili českú verziu dotazníka sociálnej opory u detí a dospievajúcich CASSS (2000) - dotazník CASSS-CZ, ktorú vytvorili Mareš a Ježek. Dotazník má 60 položiek, ktoré sú rozdelené do piatich subškál sociálnej opory (druhy sociálnej opory, poskytovatelia) zahrnujúcich rodičov, učitel'ov, spolužiakov, kamarátov a ostatných l’udí v škole. Každá položka dotazníka zachycuje jednu zo štyroch možných typov sociálnej opory, a to: emocionálnu, informačnú, hodnotiacu a inštrumentálnu. Dotazník CASSS-CZ nezist'oval položky „moja mama“ a „môj otec“ (iba spolu „moji rodičia“), tie bolo do pôvodnej metodiky doplnené Šramovou (in Hyksová, 2012), aby bolo možné zistit’ sociálnu oporu u rodičov v závislosti od ich roly. My sme toto delenie taktiež prevzali. Marešov dotazník obsahuje položku ,iní l’udia v škole“, našim zámerom bolo konkretizovat' túto položku na odborných zamestnancov pracujúcich na danej škole a to: sociálne pracovníčky a asistent učitel'a.

Vzhl'adom k tomu, že v dotazníku CASSS-CZ boli už dané zdroje sociálnej opory, žiaci si ich nemohli vyberat' a aj vzhl'adom k doplneniu informácií a rozšíreniu pohl'adu na vnímanie sociálnej opory rómskymi žiakmi sme metódu dotazníka doplnili metódou štruktúrovaného interview.

\section{Výsledky}

Na začiatok poskytujeme celkový prehl'ad zdrojov a druhov sociálnej opory bez ohl'adu na typ osídlenia respondentov.

Tabul'ka 1 Celkové hodnoty sociálnej opory - podl'a zdrojov a druhov v častosti a dôležitosti vnímanej sociálnej opory

\begin{tabular}{|l|l|l|l|l|r|}
\hline & & N & M & SEM & SD \\
\hline \multirow{2}{*}{ Sociálny pracovník } & častost' & 79 & 53,709 & 1,224 & 10,881 \\
\cline { 2 - 6 } & dôležitost' & 79 & 25,051 & 0,520 & 4,619 \\
\hline \multirow{2}{*}{ Moji učitelia } & častost' & 79 & 59,658 & 1,062 & 9,443 \\
\cline { 2 - 6 } & dôležitost' & 79 & 21,190 & 0,414 & 3,682 \\
\hline \multirow{2}{*}{ Moji spolužiaci } & častost' & 79 & 57,304 & 1,320 & 11,736 \\
\cline { 2 - 6 } & dôležitost' & 79 & 26,038 & 0,527 & 4,681 \\
\hline \multirow{2}{*}{ Moji kamaráti } & častost' & 79 & 63,785 & 1,104 & 9,812 \\
\cline { 2 - 6 } & dôležitost' & 79 & 22,405 & 0,442 & 3,924 \\
\hline \multirow{2}{*}{ Asistent učitel'a } & častost' & 79 & 53,962 & 1,522 & 13,531 \\
\cline { 2 - 6 } & dôležitost' & 79 & 24,165 & 0,588 & 5,224 \\
\hline
\end{tabular}




\begin{tabular}{|c|c|c|c|c|c|}
\hline & & $\mathbf{N}$ & $\mathbf{M}$ & SEM & SD \\
\hline \multirow{2}{*}{ Moja mama } & častost' & 79 & 64,747 & 1,218 & 10,827 \\
\hline & dôležitost' & 79 & 29,215 & 0,673 & 5,984 \\
\hline \multirow{2}{*}{ Môj otec } & častost' & 79 & 61,380 & 1,721 & 15,301 \\
\hline & dôležitost' & 79 & 28,886 & 0,678 & 6,028 \\
\hline \multirow{2}{*}{ Emocionálna } & častost' & 79 & 103,139 & 1,585 & 14,086 \\
\hline & dôležitost' & 79 & 46,734 & 0,717 & 6,374 \\
\hline \multirow{2}{*}{ Informačná } & častost' & 79 & 105,722 & 1,620 & 14,401 \\
\hline & dôležitost' & 79 & 41,823 & 0,679 & 6,035 \\
\hline \multirow{2}{*}{ Hodnotiaca } & častost' & 79 & 103,203 & 1,711 & 15,204 \\
\hline & dôležitost' & 79 & 46,152 & 0,722 & 6,417 \\
\hline \multirow{2}{*}{ Inštrumentálna } & častost' & 79 & 102,481 & 1,670 & 14,847 \\
\hline & dôležitost' & 79 & 42,241 & 0,701 & 6,234 \\
\hline
\end{tabular}

Legenda: $\mathrm{N}$ - početnost', M - priemer, SD - štandardná odchýlka, SEM - štandardná chyba priemeru

Za najdôležitejší zdroj sociálnej opory aj v dimenzii častosti, aj dôležitosti považujú naši respondenti matku. Podl'a celkovej hodnoty druhu sociálnej opory v ukazovatel'och „ako často“ je na prvom mieste informačný druh sociálnej opory a v ukazovateli ,ako dôležité“ zas emocionálny druh sociálnej opory.

V prvej hypotéze sme predpokladali, že existujú štatisticky významné rozdiely v jednotlivých zdrojoch sociálnej opory (mama, otec, učitel', kamaráti, spolužiaci, asistent učitel'a, sociálny pracovník) v častosti a dôležitosti vnímanej sociálnej opory u žiakov žijúcich v osade a u žiakov žijúcich v dedine.

Tabul'ka 2 Rozdiely $v$ zdrojoch sociálnej opory $v$ častosti a dôležitosti vnímanej sociálnej opory medzi žiakmi žijúcimi v osade a žiakmi žijúcimi v dedine

\begin{tabular}{|l|c|c|c|c|c|c|c|c|c|}
\hline \multicolumn{2}{|c|}{ Zdroj opory } & $\begin{array}{c}\text { Typ } \\
\text { obce }\end{array}$ & N & M & SD & SEM & MD & U & p \\
\hline $\begin{array}{l}\text { Sociálny } \\
\text { pracovník }\end{array}$ & častost' & osada & 61 & 55,689 & 9,653 & 1,236 & 8,689 & $\mathbf{3 3 3 , 5}$ & $\mathbf{0 , 0 1 2}$ \\
\cline { 3 - 10 } & dedina & 18 & 47,000 & 12,353 & 2,912 & 8,689 & & \\
\cline { 2 - 10 } & dôležitost' & osada & 61 & 25,738 & 4,457 & 0,571 & 3,015 & $\mathbf{3 6 5 , 5}$ & $\mathbf{0 , 0 3 1}$ \\
\cline { 3 - 10 } & dedina & 18 & 22,722 & 4,509 & 1,063 & 3,015 & & \\
\hline $\begin{array}{l}\text { Moji } \\
\text { učitelia }\end{array}$ & častost' & osada & 61 & 60,295 & 9,556 & 1,223 & 2,795 & 450,0 & 0,247 \\
\cline { 3 - 10 } & dedina & 18 & 57,500 & 8,972 & 2,115 & 2,795 & & \\
\cline { 2 - 10 } & dôležitost' & osada & 61 & 21,667 & 3,849 & 0,493 & 2,093 & $\mathbf{3 1 7 , 5}$ & $\mathbf{0 , 0 0 7}$ \\
\cline { 3 - 10 } & dedina & 18 & 19,574 & 2,512 & 0,592 & 2,093 & & \\
\hline
\end{tabular}




\begin{tabular}{|c|c|c|c|c|c|c|c|c|c|}
\hline \multicolumn{2}{|c|}{ Zdroj opory } & Typ & $\mathbf{N}$ & $\mathbf{M}$ & SD & SEM & MD & $\mathbf{U}$ & p \\
\hline \multirow{4}{*}{$\begin{array}{l}\text { Moji } \\
\text { spolužiaci }\end{array}$} & \multirow{2}{*}{ častost' } & osada & 61 & 57,967 & 11,018 & 1,411 & 2,912 & 494,0 & 0,520 \\
\hline & & dedina & 18 & 55,056 & 14,019 & 3,304 & 2,912 & & \\
\hline & \multirow{2}{*}{ dôležitost' } & osada & 61 & 26,803 & 4,922 & 0,630 & 3,359 & 312,0 & 0,005 \\
\hline & & dedina & 18 & 23,444 & 2,406 & 0,567 & 3,359 & & \\
\hline \multirow{4}{*}{$\begin{array}{l}\text { Moji } \\
\text { kamaráti }\end{array}$} & \multirow{2}{*}{ častost' } & osada & 61 & 63,213 & 10,401 & 1,332 & $-2,509$ & 469,0 & 0,346 \\
\hline & & dedina & 18 & 65,722 & 7,403 & 1,745 & $-2,509$ & & \\
\hline & \multirow{2}{*}{ dôležitost' } & osada & 61 & 22,787 & 4,164 & 0,533 & 1,676 & 360,0 & 0,026 \\
\hline & & dedina & 18 & 21,111 & 2,676 & 0,631 & 1,676 & & \\
\hline \multirow{4}{*}{$\begin{array}{l}\text { asistent } \\
\text { učitel'a }\end{array}$} & \multirow{2}{*}{ častost' } & osada & 61 & 55,230 & 13,343 & 1,708 & 5,563 & 382,0 & 0,051 \\
\hline & & dedina & 18 & 49,667 & 13,651 & 3,218 & 5,563 & & \\
\hline & \multirow{2}{*}{ dôležitost' } & osada & 61 & 24,836 & 5,505 & 0,705 & 2,947 & 348,5 & 0,018 \\
\hline & & dedina & 18 & 21,889 & 3,341 & 0,788 & 2,947 & & \\
\hline \multirow{4}{*}{$\begin{array}{l}\text { Moja } \\
\text { mama }\end{array}$} & \multirow{2}{*}{ častost' } & osada & 61 & 63,689 & 11,758 & 1,505 & $-4,645$ & 421,5 & 0,125 \\
\hline & & dedina & 18 & 68,333 & 5,678 & 1,338 & $-4,645$ & & \\
\hline & \multirow{2}{*}{ dôležitost' } & osada & 61 & 29,279 & 6,023 & 0,771 & 0,279 & 540,0 & 0,915 \\
\hline & & dedina & 18 & 29,000 & 6,020 & 1,419 & 0,279 & & \\
\hline \multirow{4}{*}{ Môj otec } & \multirow{2}{*}{ častost' } & osada & 61 & 62,082 & 13,640 & 1,746 & 3,082 & 528,0 & 0,804 \\
\hline & & dedina & 18 & 59,000 & 20,243 & 4,771 & 3,082 & & \\
\hline & \multirow{2}{*}{ dôležitost' } & osada & 61 & 28,885 & 6,011 & 0,770 & $-0,004$ & 542,5 & 0,939 \\
\hline & & dedina & 18 & 28,889 & 6,258 & 1,475 & $-0,004$ & & \\
\hline
\end{tabular}

Legenda: N - početnost', MD - rozdiel priemerov, M - priemer, U - U-hodnota, SD - štandardná odchýlka, SEM - štandardná chyba priemeru, $\mathrm{p}$ - signifikjancia

Výsledky poukazujú na rozdiely vo vnímaní sociálnej opory u žiakov žijúcich osade, ktorí považujú sociálneho pracovníka za zdroj opory, ktorý im je poskytovaný častejšie $(\mathrm{U}=333,5 ; \mathrm{p}=0,012)$ ako žiakom pochádzajúcich z dediny a taktiež jeho poskytovanú oporu považujú za dôležitejšiu ( $\mathrm{U}=365,5 ; \mathrm{p}=0,031)$ Oporu poskytovanú učitel'om považujú žiaci žijúci v osade za dôležitejšiu ako žiaci žijúci v dedine (U = 317,5; p = 0,007). Taktiež považujú oporu poskytovanú spolužiakmi $(U=312,0 ; p=0,005)$, kamarátmi $(\mathrm{U}=360,0 ; \mathrm{p}=0,026)$ aj asistentom učitel'a $(\mathrm{U}=348,5 ; \mathrm{p}=0,018)$ za dôležitejšiu než žiaci žijúci v dedine. Aj ked' sú rozdiely medzi žiakmi žijúcimi v iných typoch osídlenia v jednotlivých zdrojoch, aj čo sa týka častosti a najmä dôležitosti, ale nie vo všetkých, hypotézu č. 1 zamietame.

V druhej hypotéze sme predpokladali, že existujú štatisticky významné rozdiely v jednotlivých druhoch sociálnej opory (emocionálna, inštrumentálna, hodnotiaca a informačná) v častosti a dôležitosti vnímanej sociálnej opory u žiakov žijúcich v osade a u žiakov žijúcich v dedine. 
Tabul'ka 3 Rozdiely $v$ druhoch sociálnej opory v častosti a dôležitosti vnímanej sociálnej opory medzi žiakmi žijúcimi v osade a žiakmi žijúcimi v dedine

\begin{tabular}{|c|c|c|c|c|c|c|c|c|c|}
\hline \multicolumn{2}{|c|}{ Opora } & $\begin{array}{l}\text { Typ } \\
\text { obce }\end{array}$ & $\mathbf{N}$ & M & SD & SEM & MD & $\mathbf{U}$ & $\mathbf{p}$ \\
\hline \multirow{4}{*}{ Emocionálna } & \multirow{2}{*}{ častost' } & osada & 61 & 103,656 & 15,140 & 1,939 & 2,267 & 423,0 & 0,141 \\
\hline & & dedina & 18 & 101,389 & 9,859 & 2,324 & & & \\
\hline & \multirow{2}{*}{ dôležitost' } & osada & 61 & 47,426 & 6,912 & 0,885 & 3,037 & 383,0 & 0,052 \\
\hline & & dedina & 18 & 44,389 & 3,202 & 0,755 & & & \\
\hline \multirow{4}{*}{ Informačná } & \multirow{2}{*}{ častost' } & osada & 61 & 106,852 & 14,629 & 1,873 & 4,964 & 396,5 & 0,074 \\
\hline & & dedina & 18 & 101,889 & 13,270 & 3,128 & & & \\
\hline & \multirow{2}{*}{ dôležitost' } & osada & 61 & 42,459 & 6,451 & 0,826 & 2,792 & 414,0 & 0,114 \\
\hline & & dedina & 18 & 39,667 & 3,721 & 0,877 & & & \\
\hline \multirow{4}{*}{ Hodnotiaca } & \multirow{2}{*}{ častost' } & osada & 61 & 104,213 & 16,085 & 2,060 & 4,435 & 397,0 & 0,075 \\
\hline & & dedina & 18 & 99,778 & 11,461 & 2,701 & & & \\
\hline & \multirow{2}{*}{ dôležitost' } & osada & 61 & 46,951 & 6,854 & 0,878 & 3,506 & 372,5 & 0,039 \\
\hline & & dedina & 18 & 43,444 & 3,617 & 0,853 & & & \\
\hline \multirow{4}{*}{ Inštrumentálna } & \multirow{2}{*}{ častost' } & osada & 61 & 103,443 & 15,377 & 1,969 & 4,220 & 444,5 & 0,222 \\
\hline & & dedina & 18 & 99,222 & 12,740 & 3,003 & & & \\
\hline & \multirow{2}{*}{ dôležitost' } & osada & 61 & 43,158 & 6,538 & 0,837 & 4,029 & 314,5 & 0,006 \\
\hline & & dedina & 18 & 39,130 & 3,759 & 0,886 & & & \\
\hline
\end{tabular}

Výsledky potvrdzujú, že sú rozdiely medzi žiakmi žijúcimi v osade a na dedine v dôležitosti poskytovanej sociálnej opory a to konkrétne v týchto druhoch sociálnej opory: v emocionálnej $(U=383,0 ; p=0,052)$, hodnotiacej $(U=372,5 ; p=0,039)$ aj inštrumentálnej $U=314,5 ; p=0,006)$ sociálnej opory. Žiaci pochádzajúci z osady vnímajú tieto druhy opory za dôležitejšie než žiaci žijúci na dedine. V častosti poskytovanej sociálnej opory v jej jednotlivých druhoch sa rozdiely nepotvrdili. Aj túto hypotézu zamietame.

\section{Diskusia}

Sociálnu oporu môžeme skúmat' na rôznej vzorke populácie, ktorá sa môže líšit' pohlavím, vekom, rodinným zázemím, miestom bydliska,... i etnickou príslušnost'ou. A taktiež sociálna opora, najmä jej zdroje, či druhy opory, nemusia fungovat' u všetkých skupín obyvatel'stva rovnako. Ako zdôrazňujú Mareš, Ježek ,, určité skupiny jedincov nevyuživajú možnosti, ktoré im dáva organizovaná forma sociálnej opory. Bývajú to najmä príslušníci etnických (u nás sa to môže týkat' príslušníkov rómskeho etnika), náboženských a iných menšin. Ide o skupiny, pre ktoré je typické vyznávanie kolektívnych hodnôt vyplývajúcich zo súdržnosti vel'kých rodin “ (Mareš, Ježek, 2005, s. 9).

V nasledujúcich častiach poskytnem analýzu a interpretáciu získaných výsledkov podl'a jednotlivých zdrojov a druhov sociálnej opory a následne ich komparáciu vzhl'adom $\mathrm{k}$ typu osídlenia respondentov. 
Výsledky získané naším výskumom poukazujú na to, že pubescenti rómskeho etnika, ktorí sú žiakmi ZŠ Rakúsy, považujú za najdôležitejší zdroj sociálnej opory matku. Tá je pre nich nielen najdôležitejším zdrojom, ale opora od nej je im poskytovaná najčastejšie. Druhú pozíciu v dôležitosti a tretiu v častosti poskytovanej sociálnej opory obsadil otec. I Ondřejová a Koukola vo výskumoch realizovaných u detí a dospievajúcich $(2003 ; 2003)$ zistili, že na prvom mieste u všetkých vekových kategórií, nech sa stane čokol'vek, figuruje ako sociálna opora matka a na druhom a tret'om mieste sa objavujú bud' obaja rodičia alebo otec.

Súhlasíme s názorom Valachovej, že Rómovia sa jasne identifikujú so svojou rodinou, sú k nej pripútaní, majú hlboký pocit rodinných záväzkov aj povinností. Zvláštny fenomén rómskej rodiny predstavuje aj skutočnost', že ,,deti nerady odchádzajú od rodičov, a to ani potom, ked' sú dospelé a založia si svoje rodiny “ (Valachová et al., 2002, s. 14). To, že Rómovia sú viac závislí od rodiny, je vzhl'adom na ich izoláciu prirodzené. V rámci sledovania príslušnosti rómskych detí ku komunite Kretová (2004) vo svojom výskume zistila, že ,, z jednotlivých prostredí najvyššia príslušnost' rómskych detí sa viaže na domáce prostredie. Jednak kvôli vel'kej miere prijatia a s tým spojenej zhovievavosti tohto prostredia, no aj preto, že deti dostávajú z domu viac pozitívnych väzieb, ako z iných prostredi"“ (Kretová, 2004, s. 141). „,Tam, kde absentujú záväzky iného charakteru (profesionálna, s majoritným obyvatel'stvom), má rodina predominantnú sociálnu úlohu “(Liégeois, 1995, s. 75).

Vzt'ahová väzba medzi matkou a diet'at'om je rozhodujúcim činitel'om v procese socializácie a udáva bazálnu (ne)istotu a (ne)dôveru pre d’alšie fungovanie v sociálnej štruktúre (celkovú sociabilitu a sociálnu rezponzibilitu). V rómskej rodine žena ako matka zohráva dôležitú úlohu a v role matky má aj významné a komunitou oceňované postavenie.

Na preferovaný zdroj sociálnej opory - v našom prípade matku, sa môžeme pozriet' aj ako na prejav podporného správania v bežnom živote diet’at’a, ktorý nepôsobí len vtedy, ked' diet'a zažíva t’ažkú situáciu alebo stres, ale každodenne v sociálnych interakciách. Napr. rodič svoje diet’a podporuje nielen vtedy, ked' má problém a je zrejmé, že potrebuje oporu, ale poskytuje mu oporu iba preto, že má sociálnu rolu rodiča. Aj ked' ženy majú v rómskej rodine nižšie postavenie ako muži, žena - matka je ústrednou postavou v rodine a ako tvrdí Morvayová (2006), materinská láska rómskych žien je povestná. Morvayová (2006) uskutočnila výskum, v ktorom ciel'om bolo zistit', ako rómske deti vnímajú svojich rodičov. Matku vnímali ako vel'mi kladnú postavu a prirad'ovali jej vlastnosti zodpovedajúce tradičnej ženskej role (láskavost', nežnost', obetavost', starostlivost' o deti a domácnost').

\section{ZDROJE SOCIÁLNEJ OPORY: ROVESNÍCI (SPOLUŽIACI A KAMARÁTI)}

Za tretí najdôležitejší zdroj po matke a otcovi považujú naši respondenti svojich spolužiakov, aj ked’ častejšie im poskytujú sociálnu oporu rodičia, učitelia i kamaráti. Žiaci navštevujú školu, ktorá je, čo sa týka etnicity, homogénna. Ich spolužiaci sú Rómovia. Viacerí pochádzajú z podobného sociokultúrneho prostredia. Stierajú sa rozdiely, ktoré by boli markantnejšie, keby trieda, škola, bola heterogénna, keby ju navštevovali aj žiaci z majoritnej spoločnosti. Takže je pochopitel'né, že pre respondentov sú ich spolužiaci 
dôležitými osobami. Bolo by zaujímavé zistit', ako by vnímali rómski žiaci spolužiakov, keby boli v etnicky zmiešanom triednom kolektíve.

„S nástupom puberty a s poklesom rodičovského vplyvu rastie pre dospievajúceho význam rovesníckej skupiny, ktorá sa stáva jeho novým identifikačným vzorom " (Janošová, 2008, s. 218). Spolužiaci, rovesníci sú si blízki vekom, názormi, problémami, osudmi a čo je podstatné, trávia spolu najviac času. Pubescenti sa zoskupujú do rôznych formálnych i neformálnych skupín najmä v rámci školy, školskej triedy. Pubescenti majú vel'mi silnú potrebu niekam patrit', prijatie do skupiny im dáva pocit istoty a bezpečia. Aj na ich správanie často viac vplýva mienka spolužiakov ako učitel'ov či rodičov. Ako konštatuje Končeková, ,,neúspešné vzt'ahy so spolužiakmi, nedostatok blizkych kamarátov alebo rozpad priatel'stva vzbudzujú u pubescenta deprimujúce pocity, ktoré sú preživané ako osobná dráma. Najneprijemnejšou situáciou pre pubescenta je odsúdenie kolektívom kamarátov a najtažšim trestom je otvorený alebo tajný bojkot, nechut'sa s ním stýkat" (Končeková, 2014, s. 202).

Spolužiaci sú základom pre porovnávanie skúseností, vd’aka nim si jednotlivci môžu rozvíjat' jednotlivé sociálne kompetencie. Slúžia ako opora stávajúcej sa identity pubescenta.

Čo sa týka kamarátov, tí našim respondentom poskytujú ako druhí (po matke) najčastejšie sociálnu oporu, aj ked', a to je zaujímavé, že opora od nich nie je pre respondentov až taká dôležitá. Jednou z odpovedí na túto situáciu môže byt' skutočnost', že iné zdroje sociálnej opory sú pre nich viac potrebné v tomto období, resp. otázky z dotazníka týkajúce sa istých situácií (napr. vysvetlí mi veci, ktorým nerozumiem; povie mi, ked' sa mu páči to, čo robím; citlivo ma upozorní, ked' urobím chyby,...) nepovažujú rómski pubescenti za dôležité oblasti, resp. nepotrebujú, aby sa o týchto problémoch „bavili“ práve s kamarátmi. Informácie, ktoré sme získali metódou štruktúrovaného rozhovoru však poukazujú na to, že kamaráti sú po rodičoch a rodine, silným zdrojom sociálnej opory. V oblasti výberu strednej školy, boli prvou vol'bou, na koho sa pubescenti obrátili, ked' potrebovali poradit' ohl'adom smerovania k budúcej profesii. Súhlasíme s názorom Kebzu (2005), ktorý tvrdí, že preferovanými zdrojmi, poskytujúcimi sociálnu oporu, sú okrem rodiny práve osoby, ktoré sa výrazne podobajú svojimi charakteristikami (pohlavie, vek) a ktoré sú zoznámené $\mathrm{s}$ príslušným stresorom a jeho situačným kontextom - $\mathrm{v}$ našom prípade by sa dalo povedat', že táto možnost' sa môže vzt'ahovat' práve na osoby v období pubescencie.

\section{INŠTITUCIONALIZOVANÉ ZDROJE SOCIÁLNEJ OPORY: UČITEL, ASISTENT UČITEL'A, SOCIÁLNY PRACOVNÍK}

Ďalšie zdroje - učitel', asistenta učitel'a a sociálneho pracovníka môžeme zaradit' $\mathrm{k}$ inštitucionalizovaným zdrojom, ktoré sa nachádzajú v školskom prostredí. Inštitucionálna sociálna opora je spojená s pomocou, ktorá je zastrešovaná formálnou organizáciou, i tu samozrejme oporu zaist'ujú jednotliví l’udia, ale spravidla ako zamestnanci týchto inštitúcií, ich oporné pôsobenie je spojené najmä s výkonom ich profesie (Kebza, 2005). Škola je prvým priestorom, $v$ ktorom rómske diet’a prichádza do trvalejšej interakcie s príslušníkmi majority. Jeho úspešnost' $v$ týchto interakciách determinuje aj priebeh ostatných interakcií, ktoré má $\mathrm{v}$ d’alšom živote $\mathrm{v}$ prostredí majoritných inštitúcií. Napriek tomu, že niektoré predchádzajúce výskumy (Kundrátová, 2003; Koteková, Šimová, Gecková, 1998) poukazujú skôr na pocit’ovanie nepohody rómskych detí v základných školách, 
Kretová (2003) zistila, že škola je miesto, ku ktorému rómske deti vzt'ah rozhodne majú. $\mathrm{V}$ prvom rade nie je vnímaná konfliktne, je miestom s výraznejšou mierou pracovných aktivít a jej prostredie nie je benevolentné ako prostredie rodiny. Napriek tomu do nej deti investujú, ale aj z nej prijímajú pozitívne citové väzby. Dalo by sa povedat', že je rovnako silnou súčast'ou ich života ako domáce prostredie. Aj reakcie respondentov z nášho výskumu poukazujú na to, že niektorí žiaci sa cítia v škole príjemne. Citujeme: „chcem chodit' do školy aj cez víkend, všetko je tu dobré, chcem sa viac učit' slovenčinu, ja by som sa chcela učit' aj d'alej.“

Z výsledkov nášho výskumu vyplýva, že učitel’, učitelia poskytujú našim respondentom často sociálnu oporu, ale rómski pubescenti ich oporu nepovažujú až za tak dôležitú. V dôležitosti obsadil učitel' poslednú pozíciu. Opät' sa ponúka vysvetlenie, že potrebnú oporu získajú od svojich rodičov a učitel', ako zástupca majoritnej spoločnosti je pre nich predsa len niekto cudzí, ktorý nepatrí do ich komunity, nie je ich. Ako tvrdia Mareš a Ježek, ,sociálnej opory sa im dostáva vo vnútri ich spoločenstva, takže nepotrebujú vyhl'adávat' sociálnu oporu inde, vrátane opory profesionálnej. Nevyhl'adávajú teda učitel'ov, psychológov, sociálnych pracovníkov" (Mareš, Ježek, 2005, s. 9). Na to, aby bol proces adaptácie diet'at'a z iného sociokultúrneho prostredia v prostredí školy úspešný, je potrebné, aby edukačné prostredie (hmotné i nehmotné) bolo nastavené interkultúrne. K podobným výsledkom dospeli aj Rosenfeld, Richman (1999), ktorí realizovali výskum u vzorky žiakov druhého stupňa základnej školy a porovnával sociálnu oporu u bežných žiakov a žiakov „rizikových“, čiže žiakov zo sociálne a ekonomicky znevýhodnených rodín, žiakov, ktorí majú problémy s prospechom. Sami autori označujú niektoré výsledky za prekvapujúce. Ani pre bežných žiakov, ani pre rizikových nebol učitel' hlavným zdrojom sociálnej opory; nebol uvedený na prvom či druhom mieste ani u jedného z ôsmich skúmaných typov opory. Ak sa sústredíme na rizikových žiakov, potom ich primárnym zdrojom opory boli rodičia; s jedinou výnimkou - neurobili si dost’ času, aby svoje deti vypočuli. Opora počúvaním u rizikových žiakov chýbala. Sekundárnym zdrojom opory rizikových žiakov boli kamaráti.

$\mathrm{Na}$ druhej strane, čo sa týka nášho výskumu - prostredníctvom rozhovorov so žiakmi sme sa dozvedeli, že učitelia patria do sociálnej siete našich respondentov, ich pomoc je vítaná najmä pri problematike vol'by strednej školy. Taktiež si musíme uvedomit', že v období pubescencie sa pozícia učitel'a mení. „Citový vzt’ah $k$ učitel'ovi, ktorý prežíva mnoho detí na prvom stupni, býva v tomto veku postupne vystriedaný zvyšujúcou sa solidaritou s kolektívom triedy. V tejto dobe už nie je nedotknutel'ným zákonom to, čo povie učitel', ale to, čo proklamuje rovesnícka skupina “ (Janošová, 2008, s. 151). Nadradená rola učitel'a už nie je tabuizovaná, bežná je kritika učitel'ov, vo vzt’ahu k nim prevláda negativizmus a vzbura. V našej výskumnej vzorke prevládali chlapci, pre niektorých z nich môže byt' problém akceptovat' ženu v nadriadenej pozícii a to aj vzhl'adom na značný nepriaznivý pomer mužov a žien medzi pedagógmi, ked’že 80-90 \% učitel'ov tvoria ženy (i na danej škole).

Význam asistenta učitel'a pri práci s rómskymi žiakmi je nespochybnitel’ný. Je d’alšou formou pomoci rómskym det'om pri ich adaptácii na školu, pri sprostredkovaní kontaktu s rodinou, ktorá je rozhodujúca pre úspešný priebeh školskej práce žiakov. Ich pracovnou náplňou podl'a Kleina, Rusnákovej, Šilonovej je najmä ,,pomoc žiakom pri osvojovaní slovenského jazyka, spolupráca s učitel’om počas hodín, práca v teréne a spolupráca s rodičmi, osvetová činnost', v popoludňajšich hodinách pomoc s prípravou na 
vyučovanie, vykonávanie dozoru, sprevádzanie detí v škole a mimo školu, napr. na psychologické vyšetrenie “ (Klein, Rusnáková, Šilonová, 2012, s. 180). Aj v škole, na ktorej sme realizovali výskum podl'a vyjadrenia zástupcu školy, vykonávajú asistenti tieto činnosti, „venujú sa slabším žiakom, pomáhajú učitel’om so všetkým, čo potrebujú, jeden z nich vyučuje aj hudobnú výchovu, robia dozor na chodbách, sprevádzajú žiakov na autobus“. Aj respondenti z nášho výskumy ich považujú za dôležitý zdroj sociálnej opory, aj ked' jeho oporu nepovažujú za vel'mi frekventovanú a častú.

Podl'a vyjadrenia mnohých odborníkov asistent učitel'a pre rómskych žiakov by mal ovládat' lokálny dialekt a mal by byt' akceptovaný v rómskej komunite. Výsledky nášho výskumu poukázali na skutočnost', že rómski asistenti na danej škole ovládali rómsky dialekt, ale jedného z nich žiaci prestali akceptovat' - citujeme výroky pubescentov: ,je iba asistent a vyvyšuje sa nad nás“, „už je ako biely“, ,,je namyslený, uráža nás, už nie je ako my..." Môžeme to interpretovat' tým, že rómsky asistent už zaujal iné miesto v rómskej komunite - má prácu, peniaze, už spolupracuje s Nerómami,... už je iný a tým pádom stráca rešpekt iných Rómov. Bez nároku na zovšeobecňovanie konštatujeme, že aj táto skutočnost' mohla ovplyvnit' výsledok, že rómsky asistent sa ocitol - čo sa týka preferovaného zdroja opory - na predposlednej pozícii.

Ako sme už spomínali, d'alší zdroj opory, sociálnych pracovníkov, sme do dotazníka nezaradili náhodne, ale na základe analýzy rozhovorov so žiakmi, ktorí ich aktivity, činnosti vnímali a hodnotili pozitívne. Ich pomoc vnímajú najmä pri vypisovaní rôznych dokumentov, tlačív, sú sprostredkovatel'mi medzi žiakmi a ich rodičmi a d'alšími inštitúciami, čo je pre Rómov vel'mi dôležité. Na škole pracujú dve sociálne pracovníčky, jedna Rómka, druhá Nerómka, ktoré sú zamestnané cez projekt. Naši respondenti ich považujú za štvrtý najdôležitejší zdroj sociálnej opory - po mame, otcovi a spolužiakoch. Čo sa týka častosti, ktorú žiakom poskytujú - sú na poslednom mieste, ale to je pochopitel'né, ked’že poskytujú pomoc sprostredkovane - rodičom žiakov a to najmä v období prijímania sociálnych dávok, raz za štvrt'rok, ked'sa hodnotí dochádzka, prospech, správanie žiakov.

Dovolíme si skonštatovat', že aj ked' inštitucionalizovaná sociálna opora nie je u našich respondentov preferovaná, jej význam nadobúda najmä v situáciách, v ktorých nie sú dobre zvládnutel'né zdroje rodiny, priatel'ov, susedov. Tiež pre jednotlivcov alebo skupiny, ktoré nedisponujú takou „kvalitnou“ sociálnou siet'ou, aby mohla reagovat' na všetky ich potreby.

\section{Druhy sociálnej opory}

Čo sa týka jednotlivých druhov sociálnej opory, považujú naši respondenti za najdôležitejší emocionálny druh, aj ked' najčastejšie dostávajú informačnú oporu. Tú však považujú za najmenej dôležitú. Dôležitost' emocionálnej opory ,vyskočila“ aj pri analýze rozhovorov so žiakmi. Ich odpovede na otázku, čo potrebuješ od druhých l'udí, sa týkali najmä emocionálnej sféry a jasne naznačujú, čo pubescenti v tomto období najviac potrebujú. Citujeme: ,potrebujem: lásku, dôveru, vzt’ah, kamarátstvo, úprimnost', objatie, vypočut', aby ma mali radi, pusu,..." No a paradoxom je, že sa im dostáva najviac informácií, rád, poučiek, odporúčaní... Potrebu emocionálnej opory zdôrazňuje aj Argyle, ktorý tvrdí, že priatel'ské a kamarátske vzt’ahy nemajú len sociálnu a kognitívnu dimenziu, ale výraznú dimenziu emočnú. Pobyt s priatel'mi a kamarátmi totiž navodzuje u človeka 
príjemnú náladu. Pokial' meriame pocity radosti a št’astia z troch sociálnych situácií (pobyt s priatel'mi, pobyt s rodinou, čas trávený osamote), tak ich úroveň je najvyššia práve pri pobyte s priatel'mi. Dokonca to platí pre celý priebeh života - od 13 rokov až do vysokej staroby (Argyle, 1999). Emocionálna opora je zväčša v tomto období poskytovaná priatel'om, kamarátom, frajerom, je to opora, ktorá uist'uje o rešpekte, úcte, dôležitosti, o cene či hodnote človeka. Ako tvrdia Mareš, Ježek, ,posilňuje dôveru, zvyšuje sebahodnotenie, redukuje úzkost', strach a depresiu, motivuje aj ku zvládaniu zátažových situácii" "(Mareš, Ježek, 2005, s. 7). Naši respondenti sa nachádzajú vo vývinovom období, ktoré je charakteristické kolísaním emócií, zvýšenou labilitou, precitlivenostou, pochybnost'ami o sebe samom. Aj to môže súvisiet' so zvýšenou potrebou práve emocionálnej opory.

Hodnotiaci druh opory bol na druhom mieste aj v kategórii častosti, aj dôležitosti. Hodnotiaci typ opory sa prejavuje pochvalou, ked' človek niečo zvládne, ked' sa mu niečo podarí, ale aj citlivým upozornením, ked' robí chyby, odmenou, ked' niečo robí dobre, zhodnotením konania poskytovatel'om sociálnej opory. Je to akási spätná väzba. Tu môžeme brat' do úvahy aj potreby našich respondentov. K deficitným potrebám zarad'ujeme aj potrebu uznania človeka, úcty voči nemu, ktorá sa prejavuje túžbou byt' prospešný a preto oceňovaný, samostatný, schopný zažívat' úspech, hoci aj v každodenných veciach. Citujeme z vyjadrení respondentov: ,potrebujem spoznávat' sa, rešpekt, pravdu, spravodlivost'.“ Tieto potreby človeku saturujú najmä rodinní príslušníci, ale v školskom prostredí to môžu byt' zástupcovia z radu učitel’ov, najmä čo sa týka ocenenia.

Inštrumentálnu oporu získavajú naši respondenti najmenej často, ale ani nie je pre nich taká dôležitá. Toto zistenie nás prekvapilo, lebo najmä u žiakov žijúcich v osade sme predpokladali, že bude tento druh sociálnej opory pre nich viac dôležitý. No k podobnému poznatku dospeli aj Rusnáková a Šramková vo svojich výskumoch so žiakmi zo segregovanej rómskej komunity. Pubescentov sa pýtali, čo by museli mat', keby boli bohatí. Všetci žiaci mali za úlohu napísat' pät' indikátorov. Viac ako polovica detí z osady tento počet nenaplnila a na rozdiel od ostatných spolužiakov do svojich odpovedí často zarad’ovali osobný majetok (pekné šaty, nový mobilný telefón, vreckové, väčší dom, svoju izbu...). V odpovediach ostatných žiakov sa opakovali: firma, lietadlo, domy v zahraničí, vel’a áut, umelecké predmety (Rusnáková, Šramková, 2009). Naše výsledky mohli byt' ovplyvnené práve tým, že väčšina našich respondentov žila v osade, $\mathrm{v}$ skromných podmienkach, $\mathrm{v}$ ktorých od rodičov dostávali len to najnutnejšie na prežitie. Na danú situáciu sú viac-menej zvyknutí a môžeme skonštatovat', že ani si nemajú s kým porovnávat' svoje materiálne bohatstvo, ked’že sú si v týchto podmienkach rovní a nestretávajú sa často s rovesníkmi z majoritnej spoločnosti.

K zaujímavým poznatkom dospeli Sullivan et al. (in Mareš, 2002, s. 26-27), ktorí konštatujú, že $\mathrm{v}$ období dospievania je pre pubescentov a adolescentov t'ažké nájst' taký zdroj opory, ktorý im poskytne všetky druhy sociálnej opory. Preto ak chcú získat' overené informácie, ak chcú mat' kompetentný zdroj, tak si vyberú rodiča. Ak potrebujú starostlivost', vypočutie, idú za kamarátmi. Tieto zistenia sú dôležité práve pre poskytovatel'ov sociálnej opory, a to najmä profesionálov, aby mohli zvolit' adekvátnu a efektívnu intervenciu. 


\section{Komparácia zdrojov a druhov sociálnej opory vzhladom na typ osídlenia}

V hypotézach sme predpokladali štatisticky významné rozdiely v zdrojoch a druhoch poskytovanej opory v častosti aj dôležitosti vzhl'adom na typ osídlenia respondentov. Aj ked' sme hypotézy zamietli, v jednotlivých atribútoch boli štatisticky významné rozdiely. Výsledky poukazujú na rozdiely vo vnímaní sociálnej opory u žiakov žijúcich v osade. Tí považujú sociálneho pracovníka za zdroj opory, ktorý im je poskytovaný častejšie ako žiakom pochádzajúcich z dediny a tiež jeho poskytovanú oporu považujú za dôležitejšiu. Taktiež považujú za dôležitejšiu oporu poskytovanú učitel'om, spolužiakmi, kamarátmi, aj asistentom učitel'a než žiaci žijúci v dedine. Čiže okrem matky a otca (tí sú vnímaní ako rovnako dôležité zdroje pre všetkých respondentov) považovali deti žijúce v osade ostatné zdroje za dôležitejšie. Toto zistenie stojí za povšimnutie. Pokúsime sa ho interpretovat' cez sociálne siete. Sociálna siet', ako tvrdí Křivohlavý je ,, súbor l’udí okolo danej osoby, s ktorými je, alebo bola, táto osoba v sociálnom kontakte a od ktorých je možné očakávat', že by jej v prípade potreby poskytli určitú pomoc “ (Křivohlavý, 2001, s. 94-95). V sociológii nachádzame v súvislosti so siet’ami človeka pojmy silná a slabá väzba. Hagan (1998) vníma ako silné väzby tie, ktoré posilňujú spoločnú identitu do vnútra skupiny, sú základom solidarity a zázemia a ako slabé tie, ktoré predstavujú prepojenia aj na iné skupiny, a tak rozširujú skupinovú a osobnú identitu o d’alšie prvky, sú kanálom pre prúdenie informácií a zdrojov. Slabé, preklenujúce väzby sčasti tvoria siet' neformálnu (v našom dotazníku sú to kamaráti) a sčasti formálnu sociálnu siet' (sociálne interakcie v rámci inštitúcií - učitel', asistent učitel'a, sociálny pracovník).

Tým, že títo respondenti pochádzajú z marginalizovanej rómskej komunity, homogenita skupiny a silné väzby členov môžu viest' k uzatvoreniu skupiny a k problémom v procese sociálnej inklúzie. „Zároveň sa môžu oslabit’ preklenujúce väzby s majoritou, resp. väzby mimo komunitu, l'udia v komunite majú obmedzené životné zdroje, disponujú rovnakými informáciami, silné vzájomné väzby im poskytujú pocit istoty a bezpečia, ale obmedzujú ich možnosti integrácie " (Čerešníková, 2015, s. 17). Pozitívne je, že naši respondenti si uvedomujú dôležitost' týchto slabých, preklenujúcich väzieb, ktoré im môžu pomôct' pri získaní rôznych druhov sociálnej opory. Vidíme, že naši respondenti potrebujú kontakt s majoritným obyvatel'stvom. Ako tvrdia Rusnáková, Čerešníková, práve najchudobnejšie skupiny obyvatel'ov, medzi ktoré podl'a oficiálnych vládnych dokumentov patrí vel'ká čast' obyvatel'ov marginalizovaných rómskych komunít, má menej príležitostí pre riešenie sociálne nepriaznivej situácie $\mathrm{z}$ osobných zdrojov alebo zo zdrojov pochádzajúcich z neformálnych sociálnych sietí (rodina, priatelia). Práve v takýchto situáciách nadobúdajú význam ,formálne“ zdroje sociálnej opory, v prípade, že sú jednotlivcom alebo rodinám dostupné, a teda sú súčast’ou ich sociálnej siete. Môžu to byt’ rôzni inštitucionálni aktéri, najčastejšie na lokálnej úrovni (napr. učitelia, sociálni pracovníci - lokálni nositelia formálnej moci), ale aj miestne autority (napr. rómski aktivista, vajda) (Rusnáková, Čerešníková, 2015). Z analýzy rozhovorov vyplýva, že naši respondenti žijúci v osade, do svojej sociálnej siete, na rozdiel od respondentov žijúcich na dedine, zaradili aj starostu či lekárov - čiže dostupné zdroje opory.

Čo sa týka druhov sociálnej opory, výsledky potvrdzujú, že sú rozdiely v dôležitosti poskytovanej sociálnej opory medzi žiakmi žijúcimi v osade a na dedine. Okrem informačnej opory, vnímajú respondenti žijúci v osade emocionálnu, hodnotiacu i inštrumentálnu 
oporu za dôležitejšiu ako žiaci žijúci na dedine. V častosti poskytovanej sociálnej opory v jej jednotlivých druhoch sa rozdiely nepotvrdili. Opät' to môže súvisiet' s homogenitou - či už homogenitou osady alebo školského prostredia a menej frekventovaným kontaktom so zdrojmi z majoritnej spoločnosti.

\section{Odporúčania do praxe}

- V procese poradenskej či sociálnej práce so žiakmi rómskeho etnika považujeme za najdôležitejšiu práve prácu so sociálnou siet'ou rodiny (aj vzhl'adom na naše výsledky). Rodinné vzt'ahy sú pre deti nesmierne dôležité z aspektu ich osobnostnej integrity a poznanie ich pôsobenia a fungovania je dôležité v procese poskytovania opory, či pomoci. Podl'a Gaburu (2006) prináša práca so sociálnou siet'ou rodiny viac informácií, nové možnosti percepcie rodiny a jej jednotlivých členov, aktivizáciu latentných zdrojov. Čiže je vhodné podporit’ intenzívnejší kontakt školy s rómskou komunitou najmä prostredníctvom práce pedagogického asistenta či iných odborných zamestnancov (školský psychológ, sociálny pedagóg, sociálny pracovník).

- Vytvárat' pre žiakov rómskeho etnika vhodné podmienky na vzdelávanie a výchovu v školách a triedach spolu s majoritnou populáciou. Rómski žiaci sú často bezdôvodne umiestňovaní do segregovaných škôl oddelene od majoritnej spoločnosti (to sa týkalo aj našich respondentov). Hoci ,etnická“ homogenita školy, triedy - na jednej strane prináša výhody v tom, že žiaci sú na ,jednej lodi““ - nie sú odmietaní pre svoju etnickú príslušnost', ani pre sociálne postavenie rodiny, ale chýba kontakt s majoritnými spolužiakmi, chýba možnost' spoznávania sa, získavania d’alších sociálnych kompetencií a v neposlednom rade najmä možnost' rozšírenia sociálnej siete o iných než rodinných príslušníkov. No musíme brat' v úvahu aj riziko, že rómski žiaci budú majoritou vnímaní ako okrajoví žiaci, ako tvrdia poznatky z výskumov slovenských autorov (Kundrátová, 1995; L’uptáková, 2004; Šramková, 2009), ktoré potvrdzujú, že deti rasovo odlišné, ktoré sú integrované do bežného kolektívu, majú spravidla nízky sociometrický status v skupine. Ako tvrdí Zat'ková ,sú odmietané alebo prehliadané, nedosahujú však status priemerných alebo oblúbených “ (Zat'ková, 2002, s. 317). Súhlasíme s názorom Kleina, že je dôležitá potreba zmeny slovenského segregačného školského systému na systém integračný, inkluzívny, najmä v oblasti edukácie rómskych žiakov (Klein, Rusnáková, Šilonová, 2012, s. 57). Ak sú deti z osady, či zo sociálne málo podnetného prostredia sústredené v jednej triede, nedokážu sa navzájom motivovat' a škola tak ešte prehlbuje ich znevýhodnenie (Klein et al., 2012, s. 57). Pri tomto odporúčaní však máme dilemu - výhody, ktoré plynu z etnicky zmiešaného kolektívu (vyššia motivácia od nerómskych spolužiakov, zdokonal'ovanie sa v slovenskom jazyku, možná širšia sociálna siet', rómsko-nerómske priatel'stvá) a zároveň obavy zo zlých medzietnických vzt’ahov, ktoré by mohli rómskym žiakom ubližovat'.

- Zapájat’ žiakov do mimoškolskej záujmovej činnosti. Rómski žiaci majú obmedzené možnosti zúčastňovat' sa na spoločenskom živote - dat' im priestor v oblasti informálneho vzdelávania - v mimotriednych, mimoškolských a vo vol'nočasových aktivitách v školských kluboch detí, v centrách vol'ného času, v základných umeleckých školách a v d'alších kultúrnych a spoločenských zariadeniach. Aj tým môžeme posilnit' preklenujúce väzby s majoritou, zabezpečit’ im prepojenie na osoby a iné zdroje mimo vylúčenej lokality. 
- Realizovat' na školách programy na rozvoj sociálnych kompetencií - učit’ žiakov poskytovat' i prijímat' sociálnu oporu, ak bude programy realizovat' triedny učitel', resp. sa ich zúčastní, posilní sa medzi ním a žiakmi práve emocionálna sféra, ktorá je pre žiakov vel'mi dôležitá. , Vzt'ah medzi učitel'om a žiakom je možné vo väčšine prípadov označit' ako neosobný. Je to vzt'ah medzi rolami. Aby vzt'ah učitel'žiak mohol prerást' do osobnej roviny, musel by byt' pre tento typ vzt'ahu vytvorený väčši priestor “ (Ježek, 2006, s. 84). Ako tvrdí Mareš, ,, ak má učitel’ poskytovat’ žiakovi sociálnu oporu a ak má žiak dat' učitel'ovi vôbec najavo, že pomoc potrebuje a praje si ju ziskat', potom to nie je myslitel'né bez splnenia závažnej podmienky - musí medzi nimi vzniknút’ špecifický vzt'ah “ (Mareš, 2003, s. 47). Vzt’ahová rovina sa však netýka ,výkonu, schopností, úspechu/neúspechu, ale sociálnych súvislostí diania v škole. Ide o pozitívne vzt'ahy medzi učitel’mi a žiakmi, oporu a pomoc poskytovanú žiakom zo strany učitel'ov, redukovanie strachu a úzkosti v medziludských vzt’ahoch “ (Č́áp, Mareš, 2007, s. 588-589).

\section{Záver}

Sociálna opora je druh prosociálneho správania a pomoci, ktorý sa vyznačuje skutkami vykonanými v prospech druhej osoby, ktorá je v kríze alebo zát’aži, bez očakávania odmeny. Je to faktor modelujúci vplyv nepriaznivých životných udalostí na psychickú pohodu a zdravie. O sociálnej opore je nutné uvažovat' ako o vysoko komplexnom, dynamickom procese, ktorého forma, úroveň aj potreba je v čase premenlivá (Kahn, Antonucci, 1980). Sociálna opora má interakčné, kvalitatívne (funkčné) a kvantitatívne (štrukturálne) dimenzie, ktoré je pre správne pochopenie jej fungovania nevyhnutné zohl'adňovat'. Má všeobecný vplyv takmer vo všetkých oblastiach života. Ide o celkové kladné pôsobenie existencie dobrých vzájomných medzil’udských vzt’ahov v sociálnej sieti človeka na jeho psychický i fyzický stav. „Každá vážne mienená snaha pomôct’ druhému človeku, poskytnutie sociálnej opory (najmä ked' tým druhým je diet'a alebo dospievajúci) musí vychádzat' z poznania aktuálneho stavu “ (Mareš, Ježek, s. 12). Pri výbere z jednotlivých možností zdrojov a druhov sociálnej opory je potrebné, aby pracovníci ,pomáhajúcich“ profesií (psychológovia, sociálni pracovníci, pedagógovia, lekári,...) poznali čo najlepšie osobnost' svojho žiaka, klienta, vývinové obdobie, v ktorom sa nachádza, ale aj jeho sociálne prostredie, ktorého je súčast'ou, aby tak mohli zvolit' vhodné spôsoby intervencií a pomoci.

\section{LITERATÚRA}

Argyle, M. (1999). The Development of Social Coping Skills. In Frydenberg, E. (Ed.) Learning to Cope. New York: Oxford University Press, 81-106.

Bakaláŕ, P.(2004). Psychologie Romu. Praha: Votobia.

Bokhorst, C. L., Sumter, S. R., Westenberg, P. M. (2010). Social Support from Parents, Friends, Classmates, and Teachers in Children and Adolescents Aged 9 to 18 Years: Who Is Perceived as Most Supportive? Social Development, 19(2), 417-426.

Čáp, J., Mareš, J. (2007). Psychologie pro učitele. Praha: Portál.

Čerešníková, M. (2015). Neformálna sociálna siet - základ života v societe. In: Lehoczká, L., Rosinský, R.: Sociálna siet'v živote marginalizovaných rómskych komunit (16-36). Nitra: UKF. 
Doňková, O. (2013). Anticipovaná sociálni opora a stresovanost u pracovniků Vězeňské služby České republiky. Disertační práce. Brno: Masarykova univerzita, Filozofická fakulta Psychologický ústav.

Džambazovič, R. (2007). Priestorové aspekty chudoby a sociálneho vylúčenia. Sociológia, (3), 432-458.

Folkman, S., Lazarus, R. S. (1984). An analysis of coping in middle-aged community sample. Journal of Health and Social Behavior, (21), 219-239.

Gabura, J. (2006). Sociálna práca s rodinou. Bratislava: Občianske združenie sociálna práca.

Gecková, A., Pudelský, M., Tunistra, J. (2000). Kontakty s rovesníkmi, sociálna siet' a sociálna podpora z pohladu adolescentov. Psychológia a patopsychológia diet'ata, (2), 121-136.

Hagan, J. M. (1998). Social Networks, Gender, and Immigrant Incorporation: Resources and Constraints. American Sociological Review, (63), 55-67.

Hyksová, L. (2012). Sociálna opora adoscentov vzhl’adom na ich sociálne sposobilosti. Bakalárska práca. Olomouc.

Janošová, P. (2008). Divči a chlapecká identita: Vývoj a úskalí. Praha: Grada Publishing.

Ježek, S. (2006). Vztahy s dospělými mimo rodinu. In: Macek, P., Lacinová, L.: Vztahy v dospivaní (81-94). Brno: Barrister and Principal.

Kebza, V. (2005). Psychosociální determinanty zdraví. Praha: Academia.

Klein, V., Rusnáková, J., Šilonová, V. (2012). Nultý ročník a edukácia rómskych žiakov. Spišská Nová Ves: Roma Education Fund.

Kollárik, T.(2002). Sociálna psychológia práce. Bratislava: Univerzita Komenského v Bratislave, vydavatel'stvo UK.

Končeková, L. (2014). Vývinová psychológia. Prešov: Vydavatel'stvo Michala Vaška.

Koteková, R. (1998). Etnický kontext sociálnych kompetencií - sociálna akceptácia rómskych detí v škole. Psychológia a patopsychológia diet'ata, (2), 119-134.

Koteková, R., Šimová, E., Gecková, A. (1998). Psychológia rodiny. Košice: Pegas.

Koubeková, E. (1997). Charakteristiky sociálnej podpory pubescentov v kontexte copingu. Psychológia a patopsychológia dietata, (2), 107-114.

Koubeková, E. (2002). Sebaúcta - významný korelát sociálnej opory. Psychológia a patopsychológia dietata, (4), 335-344.

Kožený, J., Tišanská, L. (2003). Dotazník sociální opory - MOS: Vnitřní struktura nástroje. Československá psychologie, (2),135-143.

Kretová, E. (2004). Príslušnost' rómskych detí ku komunite ako vztah k domu, osade, škole a dedine. Psychológia a patopsychológia diet'ata, (2), 138-148.

Křivohlavý, J. (1999). Moderátor zvládání zátěže typu sociální opory. Československá psychologie, (2), 106-118.

Křivohlavý, J. ( 2001). Psychologie zdraví. Praha: Portál

Křivohlavý, J. (2009). Psychologie zdraví. Praha: Portál.

Kundrátová, B. (1995). Sociálno-psychologické charakteristiky postavenia rómskych detí v etnicky zmiešaných triedach ZŠ. Psychológia a patopsychológia diet'at’a, (2), 215-227.

Kundrátová, B. (2003). Možnosti ovplyvňovania etnických postojov u detí. Pedagogická revue, (2), 146-159.

Liégeois, J. P. (1995). Rómovia, cigáni, kočovníci. Bratislava: Rada Európy.

Luptáková, K. (2004). Úroveň a kvalita pripravenosti učitel’ov na realizáciu multikultúrnej výchovy na 1. stupni ZŠ. Výsledky prieskumu. Pedagogické rozhl'ady, (3), 6-11.

Mareš, J., Rybářrová, M., Lašek, J. (1996). Dvě sondy do dětského zvládaní zátěžových situací. In: Mareš, J., Furman, A.: Školni psychologie, 96(101-110). Hradec Králové.

Mareš, J. (2001). Nevyužívaní či odmítaní sociální opory. Psychológia a patopsychológia diet'at'a, (3), $214-224$

Mareš, J. (2002). Typologie sociální opory. In: Mareš et al.: Sociální opora u dětí a dospivajicich II (188-197). Hradec Králové: Nucleus.

Mareš, J. (2004). Negativní aspekty sociální opory. In: Ruisel, I., Lupták, D., Falat, M. (eds.): Sociálne procesy a osobnost' (284-294). Ústav experimentálnej psychológie SAV.

Mareš, J., Ježek, S. (2005). Dotaznik sociálni opory děti a dospivajicich. Praha: Institut pedagogicko-psychologického poradenství ČR.

Medved’ová, L'. (2001). Vplyv stresora a subjektívnej percepcie jeho zvládnutel'nosti na preferenciu a úroveň stratégií zvládania v rannej adolescencii. Psychológia a patopsychológia diet'at’a (4), 291-310.

Medved'ová, L. (2004). Zdroj stresu a zdroje jeho zvládania det’mi a adolescentmi. (Skúmanie zvládania vo VÚDPaP-e v rokoch 1999-2002). Psychológia a patopsychológia dietata, (4), 108-120. 
Morvayová, D. (2006). Kresba rodiny pri skúmaní sociálneho prostredia rómskych a nerómskych detí. Psychológia a patopsychológia diet'at'a, (3), 230-249.

Ondřejová, E., Koukola, B. (2003). Sociální opora u studentu gymnázií měrěná dotazníkem CASSS-CZ. Mareš et al.: Sociálni opora u dětí a dospivajicich III (102-110) Hradec Králové: Nucleus.

Ondřejová, E., Koukola, B. (2003). Výskum sociální opory pomocí dotazníku SSQ6 u žáků základních škol, středních škol a vyšší odborné školy. In: Mareš et al.: Sociálni opora u děti a dospívajicích III (110-120). Hradec Králové: Nucleus.

Oravcová, J., Kariková, S. (2011). Psychológia v edukácii. Banská Bystrica: Občianske združenie Pedagóg.

Radičová, I. (2001). Hic Sunt Romales. Bratislava: Nadácia S.P.A.C.E.

Rosenfeld, L. B., Richman, J. M. (1999). Supportive Communication and School Outcomes Part II. Communication Education, (4), 294-307.

Rusnáková, J. (2007). Objektívne a subjektívne charakteristiky chudoby v rómskych osadách. Rodina v novom miléniu (168-181). Nitra: UKF.

Rusnáková, J., Rochovská, A. (2014). Segregácia obyvatel’ov marginalizovaných rómskych komunít, chudoba a znevýhodnenia súvisiace s priestorovým vylúčením. Geographia Cassoviensis, (2), 162-172.

Rusnáková, J., Čerešníková, M. (2015). Sociálna opora a sociálne siete Rómov. Nitra: UKF.

Říčan, P.(1998). S Romy žit budeme, jde o to jak. Praha: Portál.

Sarason, I. G., Sarason, R. S., Pierce, G. R. (1994). Social support: Global and relationship-based levels of analysis. Journal of Social and Personal Relationships, (5), 295-312.

Schraggeová, M. (1993). Niektoré charakteristiky sociálnej podpory u absolventov vysokých škôl. Psychológia a patopsychológia dietatáa, (3), 232-243.

Šolcová, I., Kebza, V.(1999). Sociální opora jako významný protektivní faktor. Československá psychologie, (1), 19-38.

Šolcová, I. (2009). Vývoj resilience v dětství a dospělosti. Praha: Grada Publishing.

Šramková, M., Rusnáková, J. (2009). Rómske diet’a z osady v škole. Sollárová, E.: Identifikácia intelektového potenciálu a vzdelávanie rómskych žiakov (29-44). Nitra: UKF.

Šramková, M. (2009). Využitie preventívneho programu na zlepšenie sociálnych vzt’ahov v etnicky rôznorodej školskej triede. In: Fabiánová, V.: Kultúrne kontexty sociálnej interakcie a sociálnej komunikácie v etnicky zmiešaných lokálnych spoločenstvách (157-178). Nitra: UKF.

Valachová, D. et al. (2002). Vzdelávanie Rómov a multikultúrna koexistencia. Bratislava: SPN.

Vágnerová, M. (1999). Psychopatologie pro pomáhajći profese. Praha: Portál.

Vágnerová, M. (2000). Vývojová psychologie. Praha: Portál.

Výrost, J., Slaměník, I. (2001). Aplikovaná sociálni psychologie II, Praha: Grada Publishing.

Zatková, L. (2002). Zdroje sociálneho odmietania u detí školského veku. Psychológia a patopsychológia dietáa, (4), 315-323.

PhDr. Mgr. Marianna Šramková, PhD., pracuje ako odborný asistent na UMB, Inštitút manažérskych systémov v Poprade. E-mail:marianna.sramkova@gmail.com 